\title{
Characterization of isolates of Flavobacterium psychrophilum associated with coldwater disease or rainbow trout fry syndrome II: serological studies
}

\author{
Ellen Lorenzen*, Niels Jørgen Olesen \\ Danish Veterinary Laboratory, Hangovej 2, DK-8200 Århus N, Denmark
}

\begin{abstract}
The possibility of serological differentiation between isolates of Flavobacterium psychrophilum was analyzed by ELISA and slide agglutination. Twenty-five Danish isolates and 20 isolates from other European countries were studied using polyclonal rabbit antisera and whole-cell preparations. Unabsorbed as well as reciprocally absorbed antisera and purified Ig preparations derived from the antisera were included. Most of the isolates originated from clinical outbreaks of rainbow trout fry syndrome (RTFS) or coldwater disease (CWD), but some were isolated from asymptomatic fish or from other fish species with different disease signs. The ELISA showed the existence of different serotypes most distinctly, but slide agglutination supported the ELISA results. Three serotypes were found among the isolates studied: 1 major serotype (serotype Th) represented most of the Danish isolates and isolates from other European countries; 2 minor serotypes (serotypes $\mathrm{Fd}$ and $\mathrm{Fp}^{\mathrm{T}}$ ) also occurred. Serotype Th could be further divided into a major subtype, Th- 1, and a minor subtype, Th-2. Serotype $\mathrm{Fp}^{\mathrm{T}}$ was defined by the type strain $F$. psychrophilum NCIMB $1947^{\top}$, and seemed to include mostly isolates from asymptomatic fish or from fish species other than rainbow trout
\end{abstract}

KEY WORDS: Flavobacterium psychrophilum - Rainbow trout fry syndrome - Coldwater disease . Serotypes $\cdot$ ELISA $\cdot$ Slide agglutination

\section{INTRODUCTION}

Since the 1940 s, a disease named peduncle disease (Davis 1946, cited by Bullock et al. 1971), low temperature disease (Borg 1960) or (bacterial) coldwater disease (B(CWD)) (Wood \& Yasutake 1956, Holt et al. 1989) has affected fry and fingerlings of coho salmon Oncorhynchus kisutch in the USA. Rainbow trout $O$. mykiss and several other salmonids may also be affected (Bullock et al. 1971, Schachte 1983, Amos 1985, Holt 1987). During the past $10 \mathrm{yr}$, a disease known as rainbow trout fry syndrome (RTFS) has spread over most of Europe causing serious losses in rainbow trout hatcheries among fry and fingerlings (Weis 1987, Bernardet et al. 1988, Lehmann et al. 1988, Baudin-Laurencin et al. 1989, Lorenzen et al. 1991, Bruno 1992, Santos et al. 1992, Sarti et al. 1992, Toranzo \& Barja 1993).

\footnotetext{
•E-mail: el@Svs.dk
}

Whereas RTFS is typically characterized by internal pathological signs such as splenomegaly and anaemia (Bernardet et al. 1988, Baudin-Laurencin et al. 1989, Lorenzen et al. 1991, Santos et al. 1992), signs of CWD are usually external and include skin and muscle lesions on the flank or in the peduncle area (Davis 1946, Wood \& Yasutake 1956, Borg 1960, Wood 1974. Holt 1987). Larger, chronically infected fish may develop scoliosis, lordosis (Conrad \& DeCew 1967) and abnormal swimming behaviour (Kent et al. 1989, Meyers 1989).

At low water temperatures $\left(<7-8^{\circ} \mathrm{C}\right)$ such as are encountered in winter signs very similar to those described for CWD in USA have also been observed in Europe among fingerling/table-size rainbow trout (10 to $300 \mathrm{~g}$ ) (Weis 1987, Lehmann et al. 1988, Dalsgaard \& Hørlyck 1990, Bruno 1992, Santos et al. 1992, Lorenzen et al. 1997) as well as among other reared salmonid species (O. Thoresen, Norway, $\mathrm{V}$. Hirvelä-Koski \& T. Pohjanvirta, Finland, pers. 
comms.). Other non-salmonid fish species have been reported as susceptible, although exhibiting somewhat different pathological signs (Lehmann et al. 1991).

Recently, the same bacterium, Flavobacterium psychrophilum (previously Flexibacter psychrophilus/ Cytophaga psychrophila; Bernardet et al. 1996), was shown to be involved in both CWD and RTFS (Bernardet \& Kerouault 1989, Santos et al. 1992, Lorenzen et al. 1997), with the recent fulfilments of Koch's postulates for RTFS (Evensen \& Lorenzen 1996). In phenotypic studies, isolates from Denmark and other European countries proved to be very similar to strains from the USA and France studied by others. Comparative plasmid analyses, however, demonstrated differences among the European isolates and between American and European isolates (Holt 1987, Lorenzen et al. 1997). As the plasmid protiles revealed only a few plasmids to be present, some other characters were needed for distinguishing between isolates in epidemiological studies.

Using slide agglutination with rabbit antisera and whole-cell preparations, Pacha (1968) and Holt (1987) found no serological differences among 10 and 28 American isolates, respectively. Macroscopic tube agglutination and reciprocal absorption, however, demonstrated at least 2 different serotypes among 6 of the American isolates studied by Holt (1987). Wakabayashi et al. (1994) demonstrated 2 serotypes using absorbed antisera and $\mathrm{O}$-antigen preparations of Flavobacterium psychrophilum in microtiter agglutination tests: serotype $\mathrm{O}-1$ comprising isolates from coho salmon in Japan and USA, and serotype O-2 comprising isolates from ayu Plecoglossus altivelis and rainbow trout in Japan. Pacha \& Porter (1968) and Bullock (1972) found Flavobacterium columnare and F. psychrophilum to differ clearly from each other as well as from non-pathogenic cytophagas based on slideagglutination of whole cells.

The present work was undertaken to search for possible serological differences among the European isolates of Flavobacterium psychrophilum despite the phenotypic uniformity reported thus far for the organism (Lorenzen et al. 1997). The type strains F. psychrophilum NCIMB $1947^{\mathrm{T}}$ and $F$. columnare NCIMB $2248^{\mathrm{T}}$, both isolated in the USA, were included for comparison. The results of Holt (1987) and Pacha (1968) indicated that slide agglutination using unabsorbed antisera and whole cell preparations might not be sufficient for distinguishing between different serotypes. Therefore, the present study utilized both an enzyme-linked immunosorbent assay (ELISA) and the slide agglutination test, the reactants being whole cell preparations and unabsorbed as well as absorbed antisera.

\section{MATERIALS AND METHODS}

Bacterial isolates. The bacterial isolates included in our study are listed in Table 1. Isolates 1 to 25 were collected from clinical outbreaks of either CWD or RTFS in Danish fish farms during 1990-93. Isolates a to $t$ were received from other European countries and originated mostly from rainbow trout, like the Danish isolates. However, some of the non-Danish isolates were collected from other fish species having signs of disease different from CWD and RTFS. The type strains Flavobacterium columnare NCIMB $2248^{\top}\left(\mathrm{FC}^{\top}\right)$ and $F$. psychrophilum $\operatorname{NCIMB}^{\mathrm{T}}\left(\mathrm{Fp}^{\mathrm{T}}\right)$ were also included in the study.

Cultivation. The bacteria were cultivated al 15 to $17^{\circ} \mathrm{C}$ on modified Anacker \& Ordal's medium (Anacker \& Ordal 1955), henceforth referred to as Anacker \& Ordal's agar/broth enriched (AOAE/AOBE) (Lorenzen 1993).

Bacteriological identification. Identification of the isolates was based in part on the phenotypic characters described by Bernardet et al. (1990) and has been detailed in a previous study (Lorenzen et al. 1997). Briefly, these features included morphology and pigmentation of the colonies, morphology and motility of the bacteria in wet mount preparations, reactivity of colonies with the API ZYM gallery, presence of catalase, cytochrome oxidase and flexirubin, and the ability to absorb Congo red, and to hydrolyze starch and tyrosine.

Rabbit antisera. The antisera used in the study are listed in Table 2. Antisera were produced against 2 Danish isolates, no. 5 ( Th or 911209-1) and no. 14 ( $\sim$ Fd or 900530-4/2), and named anti-Th and anti-Fd, respectively. Antisera were also produced against the type strains $\mathrm{Fp}^{\top}$ and $\mathrm{FC}^{\top}$ and named anti- $\mathrm{Fp}^{\top}$ and anti$\mathrm{Fc}^{\mathrm{T}}$, respectively. Isolate $\mathrm{Th}(911209-1)$ originated from the first documented outberak of RTFS in Denmark and anti-Th was the first antiserum produced. Isolate Fd (900530-4/2), which originated from a later clinical outbreak, did not agglutinate with anti-Th and was therefore used for producing another antiserum, antiFd. The antisera were raised according to the method of Lancefield et al. (1975) with the following modifications. Bacteria were grown in AOBE for 2 to $3 \mathrm{~d}$, centrifuged $4187 \times g$ for $45 \mathrm{~min}$, washed 3 times in $0.1 \mathrm{M}$ phosphate-buffered saline (PBS) $\mathrm{pH} 7.2$, and inactivated by resuspension in $0.3 \%$ phosphate-buffered formalin at $4{ }^{\circ} \mathrm{C}$ for at least $48 \mathrm{~h}$. Before injection, the suspension was centrifuged at $4187 \times g$ for $45 \mathrm{~min}$ and the bacteria resuspended in PBS. The concentration was adjusted by spectrophotometer (520 nm) to approximately $1 \times 10^{8}$ cells $\mathrm{ml}^{-1}$. New Zealand white rabbits were given 9 intravenous injections of this suspension in the ears over a period of $3 \mathrm{wk}$. The first 
Table 1. Isolates of Flavobacterium psychrophilum included in the study

\begin{tabular}{|c|c|c|c|c|c|c|}
\hline Code & Isolate & Source: species & Tissue & Clinical signs & Geographic origin & Year \\
\hline $\mathrm{FC}^{\top}$ & F. columnare NCIMB $2248^{\top}$ & Chinook salmon & Kidney & - & Washington, USA & 1955 \\
\hline$F p^{\top}$ & F. psychrophilum NCIMB $1947^{\top}$ & Coho salmon & Kidney & CWD & Washington, USA & Unknown \\
\hline 1 & $910611-1$ & Rbt ${ }^{*}$, fry & Spleen & Costiasis ${ }^{d}$ & Denmark & 1991 \\
\hline 2 & $911209-2$ (NCIMB 13384) & Rbt, fry & Spleen & RTFS & Denmark & 1990 \\
\hline 3 & $910803-1$ & Rbt, fry & Kidney & RTFS & Denmark & 1991 \\
\hline 4 & $910516-1$ & Rbt, fry & Spleen & IPNV $^{6}$ & Denmark & 1991 \\
\hline $5(\mathrm{Th})$ & $911209-1$ (NCIMB 13383) & Rbt, fry & Spleen & RTFS & Denmark & 1990 \\
\hline 6 & $910619-1$ & Rbt, fry & Spleen & RTFS & Denmark & 1991 \\
\hline 7 & $910614-2$ & Rbt, young & Skin & CWD & Denmark & 1991 \\
\hline 8 & $911126-2$ & Rbt, young & Spleen & CWD & Denmark & 1991 \\
\hline 9 & $911126-3$ & $\mathrm{Rbt}_{\text {, young }}$ & Skin & CWD & Denmark & 1991 \\
\hline 10 & $911009-3$ & Rbt, young & Skin & CWD & Denmark & 1991 \\
\hline 11 & $910614-3$ & Rbt, young & Kidney & CWD & Denmark & 1991 \\
\hline 12 & $910614-5$ & Rbt, young & Eye & CWD & Denmark & 1991 \\
\hline 13 & $900406-1$ & Rbt, young & Kidney & CWD & Denmark & 1990 \\
\hline $14(\mathrm{Fd})$ & $900530-4 / 2$ & Rbt, fry & Intestine & RTFS & Denmark & 1990 \\
\hline 15 & $930210-1$ & Rbt, breeding fish & Eye & $(C W D)^{c}$ & Denmark & 1993 \\
\hline 16 & $930223-2$ & Rbt, young & Kidney & CWD/RTFS & Denmark & 1993 \\
\hline 17 & $930305-1$ & Rbt, breeding fish & Kidney & $(C W D)^{c}$ & Denmark & 1993 \\
\hline 18 & $930310-1$ & Rbt fry & Spleen & RTFS & Denmark & 1993 \\
\hline 19 & $930324-1$ & Rbt, young & Kidney & CWD & Denmark & 1993 \\
\hline 20 & $930407-1$ & Rbt, young & Spleen & CWD/RTFS & Denmark & 1993 \\
\hline 21 & $930413-1$ & Rbt, young & Skin & CWD & Denmark & 1993 \\
\hline 22 & $930427-2$ & Rbt, fry & Spleen & RTFS & Denmark & 1993 \\
\hline 23 & $930610-1$ & Rbt, fry & Spleen & RTFS & Denmark & 1993 \\
\hline 24 & $930611-2$ & Rbt, fry & Spleen & RTFS & Denmark & 1993 \\
\hline 25 & $930616-1$ & Rbt, fry & Spleen & RTFS & Denmark & 1993 \\
\hline $\mathrm{a}$ & UPI $293^{1}$ & Rbt, fry & Spleen & RTFS & Dorset, UK & 1992 \\
\hline b & WIL $293^{1}$ & Rbt, fry & Spleen & RTFS & Devon, UK & 1992 \\
\hline c & PT $4.1^{2}$ & Rbt, fingerling & Spleen & RTFS & Spain & 1992 \\
\hline d & $16 / 90^{3}$ & Tench $\cdot$ & Spleen & Haemorrhage & Germany & 1990 \\
\hline e & TG $28 / 86^{4}$ & Rbt, young & Blister & CWD & Touraine, France & 1986 \\
\hline $\mathrm{f}$ & Tours $5 / I^{4}$ & Carp $\cdots$ & Gills & Gill injury & Touraine, France & 1992 \\
\hline$g$ & $11522^{5}$ & Rbt, fry & Spleen & RTFS & France & 1993 \\
\hline$h$ & $11524^{5}$ & Rbt, fry & Spleen & RTFS & France & 1993 \\
\hline i & Fi $88 / 93^{6}$ & Rbt, fry & Spleen & RTFS & Switzerland & 1993 \\
\hline & Fi $147 / 93^{6}$ & Rbt, young & Spleen & RTFS/CWD & Switzerland & 1993 \\
\hline $\mathrm{k}$ & Fi $171 / 93^{6}$ & Rbt, fingerling & Spleen & RTFS & Switzerland & 1993 \\
\hline 1 & Fi $196 / 93^{6}$ & Rbt, fingerling & Spleen & $\mathrm{ICH}^{\mathrm{e}}$ & Switzerland & 1993 \\
\hline $\mathrm{m}$ & Fi $206 / 93^{6}$ & Rbt, fingerling & Spleen & None & Switzerland & 1993 \\
\hline $\mathrm{n}$ & Fi $332 / 92^{6}$ & Rbt, fingerling & Spleen & RTFS & Switzerland & 1992 \\
\hline 0 & $255 / 93^{7}$ & Brown trout.... & Skin & Skin lesion & Finland & 1993 \\
\hline p & $3441 / 93^{7}$ & Rbt, young & Skin & Skin lesion & Finland & 1993 \\
\hline$q$ & K $129-3 / 91^{8}$ & Whitefish $\cdots \cdot$ & Skin & Skin lesion & Finland & 1991 \\
\hline r & K $129-4 / 91^{8}$ & Whitefish & Skin & Skin lesion & Finland & 1991 \\
\hline s & $S 231^{9}$ & Rbt, fry & Spleen & Pale gills & Northern Ireland & 1993 \\
\hline $\mathrm{t}$ & $386 / 94^{10}$ & Brown trout, parr & Skin & Skin lesion & Norway & 1994 \\
\hline \multirow{2}{*}{\multicolumn{7}{|c|}{ 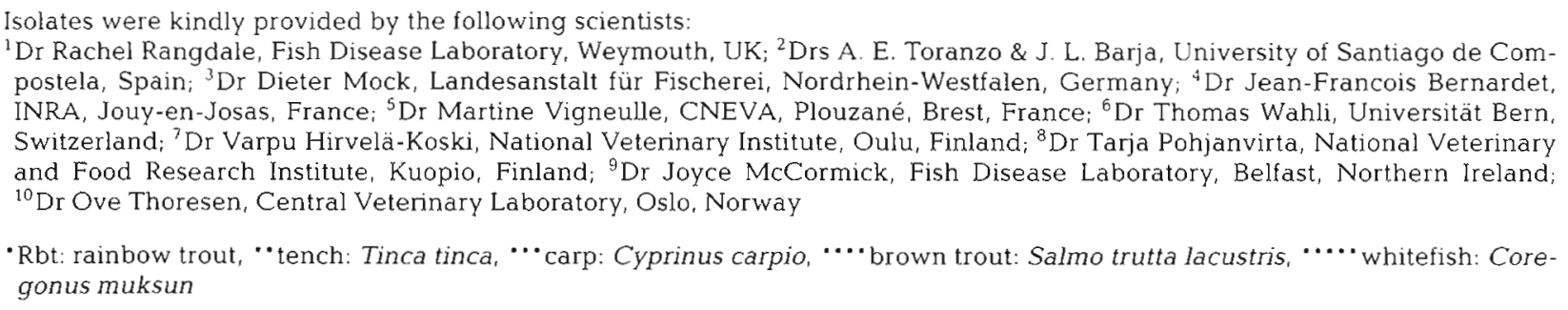 }} \\
\hline & & & & & & \\
\hline \multicolumn{3}{|c|}{ 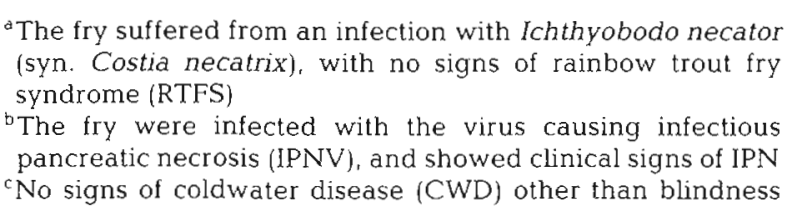 } & \multicolumn{4}{|c|}{$\begin{array}{l}{ }^{\mathrm{d}} \text { The fingerlings showed clinical signs of RTFS, and were also } \\
\text { infected with Ichthyobodo necator and with Renibacterium } \\
\text { salmoninarum, the causative agent of bacterial kidney } \\
\text { disease } \\
{ }^{\text {e }} \text { The fingerlings showed very few signs of RTFS, and were } \\
\text { recovering from an infection by Ichthyophthirius multifilis }\end{array}$} \\
\hline
\end{tabular}


Table 2. Antigens and rabbit antisera/purified IgG fractions included in the study

\begin{tabular}{|c|c|c|c|}
\hline Antigen & $\begin{array}{l}\text { Paired rabbits } \\
\text { (pooled) }\end{array}$ & $\begin{array}{l}\text { Antiserum / purified } \\
\text { purified IgG fraction }\end{array}$ & Titer $^{-}$ \\
\hline $\begin{array}{l}\text { F. psychrophilum } \\
911209-1 \text { (Th) }\end{array}$ & $\mathrm{F} 03 / \mathrm{F} 04$ & Anti-Th & 512 \\
\hline $\begin{array}{l}\text { F.psychrophilum } \\
900530-4 / 2 \text { (Fd) }\end{array}$ & $\mathrm{F} 17 / \mathrm{F} 18$ & Anti-Fd & 256 \\
\hline 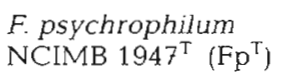 & F19/F20 & Anti-Fp ${ }^{T}$ & 128 \\
\hline $\begin{array}{l}\text { F. columnare } \\
\text { NCIMB } 2248^{\mathrm{T}}\left(\mathrm{FC}^{\mathrm{T}}\right)\end{array}$ & $F 15 / F 16$ & Anti-Fc ${ }^{\top}$ & 512 \\
\hline
\end{tabular}

azide, and by incubating overnight on a mill at $4^{\circ} \mathrm{C}$ with approximately $1 \times$ $10^{9}$ cells of each of the heterologous isolates per ml (Table 3). Following incubation, the bacterial suspensions were centrifuged at $4187 \times g$ for $1 \mathrm{~h}$ and the supernatants were recovered and filtered through a $0.45 \mu \mathrm{m}$ filter. The absorbed antisera and Ig fractions were supplemented with $1 \%$ BSA and stored at $4^{\circ} \mathrm{C}$ for up to several months. The antisera and Ig fractions were designated anti-Th ${ }^{*}$, anti-Fd ${ }^{*}$, anti-Fp ${ }^{\top}$. and anti- $\mathrm{FC}^{\top}$. following absorption (Table 3). When the absorbed antiserd or Ig fractions continued to show
3 injections were $0.5 \mathrm{ml}$ each and the subsequent 6 injections were $1.0 \mathrm{mi}$ each. The rabbits were bied $8 \mathrm{~d}$ after the last injection by incision into the ear veins. Blood was centrifuged at $1157 \times \mathrm{g}$ for $30 \mathrm{~min}$ and the serum recovered and heated at $56^{\circ} \mathrm{C}$ for $30 \mathrm{~min}$ to inactivate complement. Antisera from 2 similarly immunized rabbits were pooled (anti-Th: F03 \& F04, anti-Fd: $\mathrm{F} 17$ \& F18, anti-Fp ${ }^{\mathrm{T}}: \mathrm{F} 19$ \& $\mathrm{F} 20$, and anti-FC ${ }^{\mathrm{T}}: \mathrm{F} 15$ \& F16). The immune sera were stored undiluted at $-20^{\circ} \mathrm{C}$.

Titer: Titers of the antisera were determined by microplate agglutination modified after Davies (1990): in round-bottomed microtiter plates 2 replicates of ten 2-fold serial dilutions to $1: 1024$ of each antiserum were made in $50 \mu \mathrm{PBS}-1 \% \mathrm{BSA}$ (PBS supplemented with $1 \%$ bovine serum albumin; R. Rangdale, Weymouth, UK, pers. comm.). Approximately $1 \times 10^{6}$ bacterial cells, measured as previously, of the homologous isolate suspended in $50 \mu \mathrm{PBS}-1 \%$ BSA were added to each well. Plates were incubated on an orbital shaker at $37^{\circ} \mathrm{C}$ for $2 \mathrm{~h}$ and subsequently overnight at $4^{\circ} \mathrm{C}$. Titers, recorded visually against a dark background, were defined as the reciprocal value of the highest serum dilution showing a macroscopically visible agglutination

Purification: Purification of the immunoglobulin G ( $\mathrm{IgG}$ ) fractions in the antisera was done by protein-A sepharose affinity chromatography according to the supplier's instructions (Pharmacia). Bound IgG was eluted by means of $0.03 \mathrm{M}$ citric acid $\mathrm{pH} 3.0$, and protein concentration was determined by spectrophotometer at $280 \mathrm{~nm}\left(\mathrm{~A}_{280}=1.5\right.$ equivalent to $1 \mathrm{mg}$ protein $\mathrm{ml}^{-1}$ ). Purified IgG was biotinylated by use of N,N-hydroxysuccinimidobiotin (Sigma) as described by Tijssen (1987).

Absorption: Reciprocal absorption of antisera (for slide agglutination) and of the protein-A purified Ig fractions of the antisera (for ELISA) (Table 3) was accomplished by diluting the reagents $1: 2$ and $1: 100$, respectively, in PBS supplemented with $15 \mathrm{mM}$ sodium reactivity with the isolates used for absorption, other similar absorptions with the heterologous isolates were performed until this reactivity was removed. Using the reciprocally absorbed antisera on the Danish isolates 1 to 14 , some cross-reactivity was observed using the slide agglutination test. Further absorptions were necessary to determine to which serogroup the isolates in question belonged. Thus, anti-Th ${ }^{\circ}$ and anti-Fd ${ }^{*}$ were absorbed with two of the cross-reacting isolates (nos. 3 and 6 ), and anti-Th ${ }^{*}$ and anti-Fp ${ }^{\top}$ were absorbed with isolate no. 4.

ELISA technique. ELISA was performed using the double antibody sandwich method as described by Voller et al. (1979): flat-bottomed microtiter plates (Maxisorp Nunc-Immuno Plate, Inter Med, Teknunc, Denmark) were coated with protein-A purified Ig diluted in carbonate buffer pH 9.6 supplemented with $15 \mathrm{mM}$ sodium azide. Each well received $50 \mu \mathrm{l} \mathrm{IgG}$ solution equivalent to $0.052 \mu \mathrm{g}$ IgG purified from antiTh, $0.189 \mu \mathrm{g}$ IgG from anti-Fd, $0.062 \mu \mathrm{g}$ IgG from anti$\mathrm{Fp}^{\mathrm{T}}$, or $0.024 \mu \mathrm{g}$ IgG purified from anti- $\mathrm{FC}^{\mathrm{T}}$. The microwell plates were incubated overnight at $4{ }^{\circ} \mathrm{C}$ on an orbital shaker for adsorption. Coated microtiter plates were stored at $4^{\circ} \mathrm{C}$ for a maximum of $4 \mathrm{wk}$ in a humid chamber.

Before use, the plates were washed 3 times in PBS supplemented with $0.05 \%$ Tween 20 (PBS-T) and subsequently incubated on an orbital shaker for $1 \mathrm{~h}$ at

Table 3. Reciprocally absorbed rabbit antisera/IgG fractions

\begin{tabular}{|c|c|c|}
\hline $\begin{array}{l}\text { Antiserum/ } \\
\text { purified IgG fraction }\end{array}$ & $\begin{array}{l}\text { Isolates used } \\
\text { for absorption }\end{array}$ & $\begin{array}{c}\text { Absorbed antiserum } \\
\text { purified IgG fraction }\end{array}$ \\
\hline Anti-Th & $\mathrm{Fd}, \mathrm{Fp}^{\top}, \mathrm{FC}^{\top}$ & Anti-Th \\
\hline Anti-Fd & Th, $\mathrm{Fp}^{\mathrm{T}}, \mathrm{Fc}^{\mathrm{T}}$ & Anti-Fd. \\
\hline Anti-Fp & Th, Fd, $\mathrm{FC}^{\top}$ & Anti-Fp' ${ }^{T}$. \\
\hline Anti-FC & Th, Fd, Fp ${ }^{T}$ & Anti-FC \\
\hline \multicolumn{3}{|c|}{${ }^{\mathrm{a}}$ Code of isolates as in Tables $1 \& 2$} \\
\hline
\end{tabular}


$37^{\circ} \mathrm{C}$ or overnight at $4^{\circ} \mathrm{C}$ with bacterial cells suspended in PBS-T supplemented with $1 \%$ bovine serum albumin (PBS-T-BSA) (50 $\mu$ per well). For all of the following steps, PBS-T-BSA was used as diluent, each well receiving $50 \mu \mathrm{l}$, and all incubations were performed on an orbital shaker in a humid chamber, unless otherwise indicated.

After 3 more washes (PBS-T), the plates were incubated for $1 \mathrm{~h}$ at $37^{\circ} \mathrm{C}$ or overnight at $4^{\circ} \mathrm{C}$ with biotinconjugates prepared from the same purified IgG as used for coating. The optimum dilution of biotinylated Ig varied according to the antiserum from which it was purified. Thus each well received $0.013 \mu \mathrm{g} \operatorname{IgG}$ of antiTh, $0.025 \mu \mathrm{g}$ IgG of anti-Fd, $0.031 \mu \mathrm{g}$ IgG of anti-Fp', and $0.027 \mu \mathrm{g}$ IgG of anti-Fc ${ }^{\mathrm{T}}$. Following 3 additional washings, the plates were incubated for $1 \mathrm{~h}$ at $37^{\circ} \mathrm{C}$ with peroxidase conjugated streptavidin (DAKO, Denmark) diluted 1:2000. After a final wash, all wells received the substrate $\mathrm{H}_{2} \mathrm{O}_{2}$-ortho phenylenediamine (OPD, Kem-en-Tec, Denmark) diluted in phosphatebuffered citric acid pH 5.0. The substrate was incubated for $15 \mathrm{~min}$ at room temperature and the reaction was stopped with $1 \mathrm{M} \mathrm{H}_{2} \mathrm{SO}_{4}(100 \mu \mathrm{l}$ per well). Subsequently, the absorbance was measured by a Titertek Multiscan reader at a wavelength of $492 \mathrm{~nm}\left(\mathrm{~A}_{492}\right)$.

The concentration of IgG in the coating layer and in the biotinylated layer was adjusted to obtain a background value $\left(\mathrm{A}_{492}\right)$ below 0.2 and a maximum value of about 2.5 for the homologous antigen. Absorbed IgG fractions (anti-Th ${ }^{*}$, anti-Fd ${ }^{*}$, anti- $\mathrm{Fp}^{\mathrm{T}}{ }^{*}$ and anti-FC ${ }^{\top}{ }^{*}$ ) were not used for coating, but only for the biotinylated layer, and the concentration of IgG was adjusted according to the same criterion as for unabsorbed IgG fractions.

The bacteria used in the ELISA were grown in AOBE on an orbital shaker for 2 to $3 \mathrm{~d}$, washed once in PBS, and suspended in PBS with $15 \mathrm{mM}$ sodium azide to a density equivalent to approximately $1 \times 10^{10}$ colony forming units (CFU) per ml. Occasionally, 2 to $3 \mathrm{~d}$ old colonies were suspended directly in PBS with sodium azide. The bacterial suspension was heated for 10 to 15 min at $55^{\circ} \mathrm{C}$ according to Anacker \& Ordal (1959) and Holt (1987) to eliminate nonspecific aggregation. Suspensions were stored at $4{ }^{\circ} \mathrm{C}$ for a maximum of $14 \mathrm{~d}$ or at $-20^{\circ} \mathrm{C}$ for up to several months. For application on coated microwell plates, the heat-treated bacterial suspensions were diluted in PBS-T-BSA to an optical density of $0.2 \pm 0.01$ at $520 \mathrm{~nm}$, equivalent to approximately $1 \times 10^{8} \mathrm{CFU}$ per ml. Beginning with this concentration, seven 5 -fold serial dilutions were made to a final dilution of 78125 .

The following ELISA performance controls were included: (1) wells coated with purified Ig from a heterologous antiserum (anti-pike fry rhabdovirus; anti-PFR), (2) wells without bacteria, (3) wells with
PBS-T-BSA in place of biotinylated antiserum in the third layer, (4) wells with biotinylated Ig from a heterologous antiserum (anti-viral haemorrhagic septicemia virus; anti-VHSV), and (5) wells without HRP-streptavidin conjugate. Control wells without bacteria were included in each test to estimate the background optical density.

For statistical comparison of the reactivities in ELISA, an index, $m$, was calculated for each isolate tested with each purified Ig-fraction. Index $m$ represents the mean $\mathrm{A}_{492}$ of antigen dilution $1: 25,1: 125$ and 1:625. Comprising the central part of the ELISA curve, these 3 dilutions were considered representative of the reactivity for a given antigen with a given antibody preparation. The means of the $m$-values of different groups of isolates were compared by a modified Student's $t$-test for small samples (Campbell 1974), each group comprising isolates with similar reactivity.

Slide agglutination. The method described by Anacker \& Ordal (1959) was followed with a few modifications: colonies of bacteria grown for 48 to $72 \mathrm{~h}$ were suspended in sodium acetate buffer $10.05 \mathrm{M}$ $\mathrm{NaCO}_{2} \mathrm{CH}_{3}, 0.1 \mathrm{M} \mathrm{NaCl}, \mathrm{pH}$ 7.5) to a density equiva-

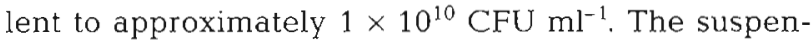
sions were heated at $55^{\circ} \mathrm{C}$ for 10 to $15 \mathrm{~min}$ as described for the ELISA preparations, and subsequently $15 \mathrm{mM}$ sodium azide was added. The preparations were stored at $4^{\circ} \mathrm{C}$ for a maximum of $14 \mathrm{~d}$. The antisera were used undiluted and diluted 1:2,1:4, 1:6 and 1:8 in PBS. Absorbed antisera were used undiluted. Ten $\mu$ l of antiserum was allowed to react with 10 to $15 \mu \mathrm{l}$ of the bacterial suspensions on a slide using a careful rocking motion. The reaction was recorded macroscopically against a dark background after 1 to 2 min. As a control for autoagglutination, preimmunization serum was used in an equivalent dilution

Plasmid analysis. Plasmid analysis was performed as previously described (Lorenzen et al. 1997).

\section{RESULTS}

\section{Bacterial isolates}

All isolates were identified as Flavobacterium psychrophilum according to their phenotypic properties as detailed previously (Lorenzen et al. 1997).

\section{Antisera}

The titer of the antisera used in our study ranged from 128 to 512 as determined by microtiter agglutination (Table 2). 


\section{Slide agglutination}

The results of the slide agglutination studies using unabsorbed antisera are not presented as these results were not meaningful. High levels of cross-reactivity were observed unless the antisera were diluted at least $1: 6$, and this dilution gave a reactivity too faint to read with certainty

The results of the slide agglutination studies using reciprocally absorbed antisera are presented in Table 4 . Most isolates (27 out of 45 ) agglutinated with antiserum anti-Th "; some (8) reacted with antiserum anti$\mathrm{Fd}^{*}$, and some (8) reacted with anti- $\mathrm{Fp}^{\mathrm{T}}$. The 4 isolates from other European countries reacting with anti-Fd" also reacted with anti-Fp $\mathrm{p}^{\top}(\mathrm{g}, \mathrm{k}, \mathrm{m}, \mathrm{q})$. Two isolates could not be placed, either due to autoagglutination (p) or lack of reactivity ( $r$ ). None of the isolates reacted with anti- $\mathrm{Fc}^{\mathrm{T}} \boldsymbol{\theta}$, and likewise $\mathrm{Fc}_{\mathrm{c}}^{\mathrm{T}}$ did not react with any of the absorbed antisera raised against isolates of Flavobacterium psychrophilum.

Among the isolates reacting with anti-Th ${ }^{*}, 5$ isolates reacted with anti-Fd ${ }^{\bullet}, 2$ isolates reacted with anti-Fp ${ }^{\top}$, and 4 isolates reacted with both anti-Fd and anti- $\mathrm{Fp}^{\mathrm{T}}$. Following absorption of anti-Fd ${ }^{\cdot}$ and anti- $\mathrm{Fp}^{\mathrm{T}}$ - with selected cross-reacting isolates (nos. 3 \& 6 , and 4, respectively), this cross-reactivity was removed without removing the reaction with the homologous isolates, $\mathrm{Fd}$ and $\mathrm{Fp}^{\mathrm{T}}$, respectively. By contrast, if antiserum anti-Th " was absorbed with the selected cross- reacting isolates, the reactivity to the homologous antigen, Th, was not retained. Therefore, the cross-reacting isolates were considered more closely related to isolate Th than to the isolates $\mathrm{Fd}$ or $\mathrm{Fp}^{\top}$.

Table 4. Slide agglutination and ELISA results for 25 Danish isolates and 20 isolates from other European countries and 2 type strains $\left(\mathrm{Fp}^{\top} \& \mathrm{FC}^{\top}\right)$ using reciprocally absorbed antisera (agglutination) or purified IgG preparations (ELISA)

\begin{tabular}{|c|c|c|c|c|c|c|c|}
\hline \multirow{2}{*}{\multicolumn{2}{|c|}{$\underbrace{\begin{array}{r}\text { ELISA, } \\
\text { serotype }\end{array}}_{\begin{array}{l}\text { Agglutination, } \\
\text { serotype }\end{array}}$}} & \multicolumn{2}{|c|}{ Th $\cdot(27) \cdot \cdot$} & \multirow[t]{3}{*}{ Fd $(8)$} & \multirow[t]{3}{*}{$F p^{T}(3)$} & \multirow[t]{3}{*}{$? \cdots(7)$} & \multirow[t]{3}{*}{$\mathrm{Fc}^{\top}$} \\
\hline & & Th-1 (18) & Th-2 (9) & & & & \\
\hline \multirow[t]{4}{*}{$\begin{array}{l}\mathrm{Th}^{\mathrm{b}} \\
(27)\end{array}$} & Th (16) & $\begin{array}{l}\text { a (Th), 7, 8, 9, } \\
10,11,12,16, \\
18,20,22,24 \\
25, \mathrm{j}, \mathrm{n}\end{array}$ & 13 & & & & \\
\hline & Th-Fd $(5)^{c}$ & i & $3,6,19, b$ & & & & \\
\hline & Th-Fd-Fp ${ }^{T}(4)^{d}$ & & $23, c, e, h$ & & & & \\
\hline & Th-Fp ${ }^{\top}(2)^{e}$ & $4, a$ & & & & & \\
\hline \multirow[t]{2}{*}{ Fd (8) } & Fd (4) & & & $2,14(\mathrm{Fd}), 15,21$ & & & \\
\hline & $\mathrm{Fd}-\mathrm{FP} \mathrm{p}^{\mathrm{T}}(4)^{f}$ & & & $g, k, m, q$ & & & \\
\hline$F p^{\top}(8)$ & & & & & $1, d, t, F p^{T}$ & $17, \mathrm{f}, \mathrm{l}, \mathrm{o}, \mathrm{s}$ & \\
\hline$? \cdots(2)$ & & & & & & $p, r$ & \\
\hline $\mathrm{Fc}^{\mathrm{T}}$ & & & & & & & $\mathrm{FC}^{\mathrm{T}}$ \\
\hline \multicolumn{8}{|c|}{ 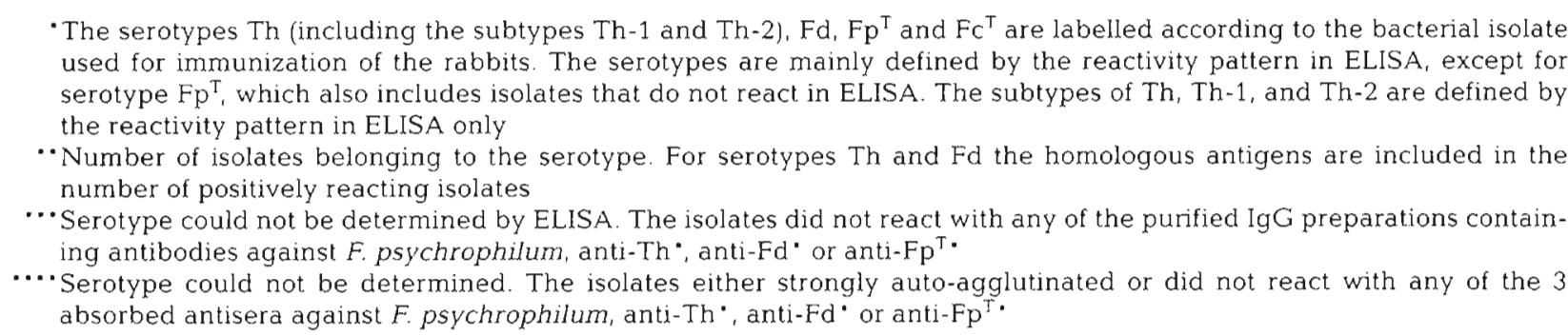 } \\
\hline \multicolumn{8}{|c|}{ 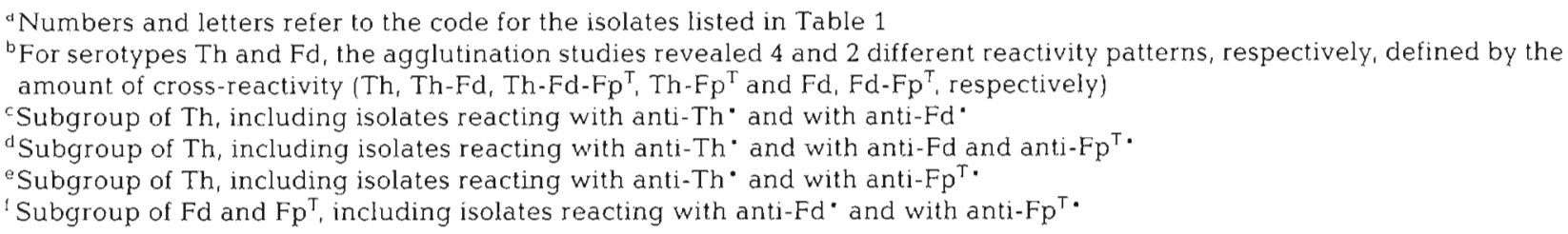 } \\
\hline
\end{tabular}


icantly $(p<0.05)$ from the weakly reacting isolates (Table 5, only presented for anti-Th). For anti-Th, the moderately reacting isolates (Th-2) also differed significantly from the strongly (Th-1) as well as the weakly reacting isolates (Table 5). Based on the strong reactivities, the 14 isolates studied fell into 3 groups with 1 of the groups consisting of 2 subgroups. Each isolate belonged to only 1 group, henceforth referred to as serotype. According to this scheme, $\mathrm{FC}^{\top}$ belonged to its own serotype. The serotypes are referred to according to the name of the homologous isolate of the antibody preparation defining the group. Serotype Th comprise 2 subtypes, subtype Th-1 consisting of the isolates reacting strongly with anti-Th, and subtype Th-2 consisting of the isolates reacting moderately with anti-Th.

Fig. 1 shows the reactivity pattern against anti-Th of $F c^{T}$ and of isoldtes of the 3 serolypes Th $(1 \& 2)$, Fd and $\mathrm{Fp}^{\top}$, represented among isolates 1 to 14 . Serotype $\mathrm{Fp}^{\top}$ also included the homologous strain $\mathrm{Fp}^{\mathrm{T}}$. Reciprocal reactivity patterns were found using the other purified IgG- preparations (anti- $\mathrm{Fd}$, anti- $\mathrm{Fp}^{\mathrm{T}}$ and anti- $\mathrm{FC}^{\mathrm{T}}$ ), except that serotype Th- 2 in these cases could not be differentiated from serotype Th-1 (results not shown). Using anti- $-\mathrm{Fc}^{\top}$, there was essentially no reactivity with any of the isolates of Flavobacterium psychrophilum studied (data not shown).

Fig. 2 shows the reactivity pattern with anti-Th of the same 14 isolates and 2 type strains following reciprocal absorption. It is evident that the reactivities of the 8 isolates within serotype Th- 1 and the 3 isolates within serotype Th-2 were retained, whereas the reactivities of the weakly reacting isolates belonging to serotype $\mathrm{Fd}$ and $\mathrm{Fp}^{\mathrm{T}}$, and of $\mathrm{Fc}^{\mathrm{T}}$ were removed. Similarly, for the other 3 antibody preparations studied, only the reactivities of the strongly reacting isolates were retained following reciprocal absorption (results not presented). The absolute values in Figs. 1 \& 2 cannot be directly compared, as the tests were not performed simultaneously.

Absorption of anti-Th * with 3 isolates (nos. 3,6, and 13) belonging to serotype Th-2 removed the reactivity to serotype Th-2. However, the reactivity to serotype Th-1 was retained though slightly lowered (data not shown).

Inclusion of the other 11 Danish isolates and the 20 isolates from other European countries in the ELISA studies apparently did not change the frequency of the 3 serotypes markedly
(Table 4). Thus out of a total of 45 isolates serotypes Th $\mathrm{Fd}$, and $\mathrm{Fp}^{\mathrm{T}}$ contained 27, 8, and 3 isolates, respectively. One Danish isolate (no. 17) and 6 isolates from other European countries ( $f, l, o, s, p, r)$ could not be related to any of the serotypes. Six isolates in addition to nos. 3,6 and 13 were found to belong to subtype Th-2 $(19,23, b, c, e, h)$.

Comparison of our ELISA results with those obtained by slide agglutination (Table 4) showed that the reactivity patterns were very similar: (1) except for 3 isolates $(4, a, i)$ the isolates of serotype Th- 1 in ELISA all reacted only with antiserum anti- $\mathrm{Th}^{*}$ in slide agglutination; (2) 8 of the 9 isolates of serotype Th-2 in ELISA reacted in slide agglutination with antiserum anti-Fd ${ }^{*}$ $\left(3,6,19\right.$, b) or with antisera anti-Fd ${ }^{*}$ and anti-Fp ${ }^{T} \cdot(23$, $c, e, h$ ) in addition to anti- $\mathrm{Th}^{-}$, but were considered more closely related to serotype $T h$ based on the absorption studies discussed previousiy; (3) the 4 Danish isolates of serotype Fd in ELISA reacted only with antiserum anti-Fd ${ }^{*}$ in slide agglutination, whereas the 4 isolates from other European countries also reacted with anti- $-\mathrm{Fp}^{\mathrm{T}} ;(4)$ the 3 isolates of serotype $\mathrm{Fp}^{\mathrm{T}}$ and 5 of the 7 isolates that could not be related to any serotype by ELISA agglutinated with antiserum anti$F p^{\Upsilon} \cdot$. Two isolates $(p, r)$ could not be placed by either method.

In Table 6, the distribution of the isolates according to serotype is compared with previous results of plasmid analyses on the same 25 Danish isolates and 20 isolates from other European countries (Lorenzen et al. 1997). This comparison revealed that most isolates of serotype Th and Fd had a plasmid of $3.2 \mathrm{~kb}$, whereas isolates belonging to serotype $\mathrm{Fp}^{\top}$ generally had different plasmid profiles.

Table 6 . Size of plasmid(s) according to serotype in 25 Danish isolates and 20 isolates of Flavobacterium psychrophilum from other European countries and the 2 type strains $\mathrm{Fp}^{\top}$ and $\mathrm{Fc}^{\top}$

\begin{tabular}{|c|c|c|c|c|c|}
\hline $\begin{array}{l}\text { Size of plas- } \\
\operatorname{mid}(\mathrm{s})(\mathrm{kb})^{a}\end{array}$ & \multicolumn{5}{|c|}{ Serotype $^{\mathrm{b}}$} \\
\hline 3.2 & $\begin{array}{l}3,5(\text { Th) }, 6,7, \\
8,9,10,11,12, \\
13,16,18,19, \\
20,22,23,24,25 \\
a, b, c, e, h, i, j, n\end{array}$ & $\begin{array}{l}2,14(\mathrm{Fd}), 21 \\
\mathrm{~g}, \mathrm{k}, \mathrm{m}\end{array}$ & $s, t$ & $\mathrm{p}$ & \\
\hline 2.4 & & & $F p^{T}$ & & \\
\hline 0 & 4 & $q$ & $1, d, 1, o$ & r & $\mathrm{Fc}^{\top}$ \\
\hline $5.7+2.2$ & & & $\mathrm{f}$ & & \\
\hline $3.2+2.6$ & & 15 & 17 & & \\
\hline \multicolumn{6}{|c|}{$\begin{array}{l}\text { d Molecular weight in kilobases }(\mathrm{kb}) \\
\text { "Numbers and letters refer to the Danish and foreign isolates, respectively, } \\
\text { listed in Table } 1 \\
\text { 'Serotype not determined }\end{array}$} \\
\hline
\end{tabular}




\section{DISCUSSION}

The present study revealed that, among 25 Danish isolates and 20 isolates of Flavobacterium psychrophilum from other European countries primarily originating from diseased rainbow trout, at least 3 distinct serotypes could be demonstrated. One of the serotypes, Th, included the majority of the isolates, with the remainder being of 2 minor serotypes, $\mathrm{Fd}$ and $\mathrm{Fp}^{\mathrm{T}}$.

The ELISA technique and slide agglutination test generally supported each other, in that results were very similar using either technique, i.e. isolates that in ELISA reacted with 1 of the 3 purified IgG preparations (anti-Th, anti-Fd \& anti-Fp ${ }^{\mathrm{T}}$ ) also reacted with the corresponding antiserum in slide agglutination. The opposite was, however, not always the case due to cross-reactivity in slide agglutination. In ELISA, no cross-reactivity among the 3 serotypes was observed following reciprocal absorption. Therefore the ELISA was considered more appropriate for defining the serotypes. However, slide agglutination was useful for defining serotype $\mathrm{Fp}^{\top}$, which ELISA did not differentiate consistently.

Absorptions of purified IgG fractions and antisera were performed at different dilutions, which might have resulted in a better absorption of the former than the latter. The criteria, however, for accepting the result of the absorptions were similar as described in 'Materials \& methods' and therefore the results of slide agglutination should have paralleled closely those obtained by ELISA. ELISA and slide agglutination, however, are based on 2 different principles, the former relying on the simple binding of antibodies to antigens, the latter on the ability of antibodies to cross-link antigens. Therefore exactly congruent results cannot always be expected. In addition, the antibody preparations used for the 2 techniques in the present study were not identical, even if originating from the same sera: for agglutination, a low dilution of absorbed serum was used, whereas high dilutions of the IgG fraction of serum were used for ELISA. Also, agglutination may partly rely on IgM-antibodies (Roitt 1984), which have lower specificity but higher avidity compared to IgG, which could explain the somewhat broader specificity of the agglutination test compared to ELISA.

The extraordinary high level of cross-reactivity of subtype Th- 2 by agglutination, and its moderate reactivity with anti-Th in ELISA might indicate that it should be considered a fourth serotype. Further studies using antiserum raised against one of the isolates within serotype Th-2 may resolve this question.

Previous plasmid analyses of the same isolates as presently studied (Lorenzen et al. 1997) revealed that bacteria from clinical outbreaks of RTFS or CWD had 1 small plasmid of approximately $3.2 \mathrm{~kb}$. By contrast, isolates from fish species other than rainbow trout or from asymptomatic fish, in general, did not have any plasmids or had 2 plasmids. Interestingly, most of these latter isolates were also somewhat different serologically. They either agglutinated with anti- $\mathrm{Fp}^{\top}$ or could not be placed in any of the 3 serotypes defined above by slide agglutination and ELISA (Table 6 ). This relationship between serological differences and plasmids suggests that part of the epitopes identified by the techniques in our study could be associated with bacterial plasmids. A possible relationship between plasmids and cell surface characteristics has been demonstrated for other bacterial fish pathogens (Toranzo et al. 1983).

None of the isolates classified as $\mathrm{Fp}^{\mathrm{T}}$ by ELISA and/or slide agglutination originated from clinical outbreaks of RTFS/CWD. Isolates comprising serotype Th-1, Th-2 or Fd originated, with few exceptions, from rainbow trout having clinical signs of RTFS or CWD. Hence, it is possible that isolates of serotype $\mathrm{Fp}^{\mathrm{T}}$ are less pathogenic, at least for rainbow trout. As the number of isolates within serotype $\mathrm{Fp}^{\mathrm{T}}$ (8) was small, more studies, including challenge experiments, are needed to elucidate this matter. The type strain $\mathrm{Fp}^{\mathrm{T}}$, which was used for preparation of our anti- $\mathrm{Fp}^{\top}$, originated from a coho salmon from the USA with signs of CWD (Holt 1987). Several passages on artificial medium could have resulted in an attenuated strain with changed surface characteristics. It is also possible that $\mathrm{Fp}^{\top}$ and serologically related isolates could be more pathogenic for coho salmon than for rainbow trout. The strains isolated by Toranzo \& Barja (1993) from an outbreak of RTFS in Spain also failed to react with antiserum produced against the type strain. Similarly, Wakabayashi et al. (1994) demonstrated that while isolates (including $\mathrm{Fp}^{\mathrm{T}}$ ) from coho salmon belonged to serotype $\mathrm{O} 1$, isolates from ayu and rainbow trout belonged to another serotype, $\mathrm{O} 2$.

By use of intramuscular injection, Holt (1987) found the type strain to be highly pathogenic for yearling coho salmon and found varying degrees of pathogenicity among his other strains of Flavobacterium psychrophilum. However, intramuscular injection may not be the most appropriate method for testing the pathogenicity of the bacterium as this bypasses the natural host defense mechanisms of the external surfaces and facilitates entrance of the bacterium. If serotype $\mathrm{Fp}^{\top}$ is less pathogenic for rainbow trout, there may be some relationship between serological properties, virulence and plasmid content. Crosa et al. $(1977,1980)$ demonstrated that the presence of a 50 megadalton plasmid was closely correlated with virulence of Vibrio anguillarum. Pathogenicity studies including different serotypes and native versus plasmid-cured isolates of $F$. 
psychrophilum might elucidate any correlations among virulence, serotype and plasmid profile that exist.

Isolates from clinical outbreaks of RTFS and CWD did not differ serologically according to the results of the present study. Isolates of serotypes $\mathrm{Th}$ and $\mathrm{Fd}$ where obtained from either disease and both serotypes have been found at the same hatcheries in Denmark.

The high level of cross-reactivity in the present study using unabsorbed antiserum on whole cells for slide agglutination was in accordance with the results of Holt (1987) and Pacha (1968). Holt (1987) found 2 serotypes among 6 isolates of Flavobacterium psychrophilum following reciprocal absorption, but unfortunately he did not study $\mathrm{Fp}^{\mathrm{T}}$, making comparison of the American strains with our European isolates difficult. Likewise, following absorption, Wakabayashi et al. (1994) demonstrated serotypes O1 and O2 among isolates of $F$. psychrophilum originating from coho saimon and from ayu and rainbow trout, respectively.

Preparations of O-antigens as described by Kauffman (1944) for Escherichia coli were also examined by us in parallel with whole-cell preparations. However, these generally autoagglutinated and were not useful for slide agglutination. In the ELISA they showed a much lower level of reactivity compared to whole-cell preparations regardless of the antibody preparation used (data not shown). Thus, a major part of the epitopes recognized by the present antisera and purified $\operatorname{lgG}$ preparations in slide agglutination and ELISA, respectively, was lost using a conventional protocol for O-antigen preparation. De Jong et al. (1991) tried without success to extract LPS (of which the O-antigen is the outermost part) from Cytophaga johnsonae (recently reclassified as Flavobacterium johnsoniae, Bernardet et al. 1996) using the phenol-water procedure of Westphal \& Jann (1965). Flavobacterium johnsoniae, F. columnare and $F$. psychrophilum all belong to the bacterial order Cytophagales (Reichenbach \& Dworkin 1981) and probably have structural properties in common. The results of De Jong et al. (1991) indicated that the methods commonly used for extracting LPS from Enterobacteriaceae and related bacteria might not be directly applicable to bacteria belonging to Cytophagales. Wakabayashi et al. (1994) found, however, that $\mathrm{O}$-antigen preparations were useful for serotyping in microtiter trays.

Using live cells, as did Pacha (1968), Pacha \& Porter (1968) and Bullock (1972), we found no detectable differences compared to heat-treated cells in ELISA. But the slide agglutination test was easier to perform on heat-treated cells, because unlike live unheated cells, they did not autoagglutinate. Whole-cell preparations have also been considered convenient for the ELISA by other authors (Cumming et al. 1980, Ison et al. 1981, Elder et al. 1982, Mills et al. 1982, Bishop \& Hwang 1992).
In conclusion, based primarily on ELISA and to a lesser degree on slide agglutination, and on the use of whole cells and polyclonal antibodies, the present study demonstrated 3 serotypes among 25 Danish isolates and 20 isolates from other European countries of Flavobacterium psychrophilum. Two of the isolates from other European countries could not be classified by either method. One serotype, Th, comprised most of the isolates, serotype Fd included few isolates, and the serotype $\mathrm{Fp}^{\mathrm{T}}$, defined by the type strain $\mathrm{Fp}^{\mathrm{T}}$, predominantly included isolates that did not originate from true outbreaks of RTFS or CWD. Pathogenicity studies, however, are necessary to elucidate any correlation among serological characteristics, virulence and plasmid profile.

Acknowledgements. Thanks are due to Dr Niels Einar Jensen, Danish Veterinary Laboratory, Copenhagen, for kind instructions concerning production of rabbit antiserum, and to colleagues for supplying isolates from other European countries (Table 1). Drs Jens Ledet Jensen and Carl Christian Danielsen, University of Aarhus, and Dr Erik Rattenborg, Danish Veterinary Laboratory, Aarhus, are acknowledged for statistical assistance and for help in preparing the figures.

\section{LITERATURE CITED}

Amos K (1985) Procedures for the detection and identification of certain fish pathogens, 3rd edn. Fish Health Section, American Fishery Society, Corvallis, OR

Anacker RL, Ordal EJ (1955) Study of a bacteriophage infecting the myxobacterium Chondrococcus columnaris. J Bacteriol 70:738-741

Anacker RL, Ordal EJ (1959) Studies on the myxobacterium Chondrococcus columnaris. I. Serological typing. J Bacteriol 78:25-32

Baudin-Laurencin F, Castric JC, Vigneulle $M$, Tixerant $G$ (1989) La myxobactériose viscérale de la truite arc-en-ciel Salmo gairdneri R: une forme nouvelle de la maladie de l'eau froide à Cytophaga psychrophila. Bull Acad Vét Fr 62:147-157

Bernardet JF, Baudin-Laurencin F, Tixerant G (1988) First identification of 'Cytophaga psychrophila' in France. Bull Eur Assoc Fish Pathol 8:104-105

Bernardet JF, Campbell AC, Buswell JA (1990) Flexibacter maritimus is the agent of 'black patch necrosis' in Dover sole in Scotland. Dis Aquat Org 8:233-237

Bernardet JF, Kerouault B (1989) Phenotypic and genomic studies of 'Cytophaga psychrophila' isolated from diseased rainbow trout (Oncorhynchus mykiss) in France. Appl Environ Microbiol 55:1796-1800

Bernardet JF, Segers $P$, Vanvanneyt $M$, Berthe F, Kersters $K$, Vandamme P (1996) Cutting a gordian knot: emended classification and description of the genus Flavobacterium, emended description of the family Flavobacteriaceae, and proposal of Flavobacterium hydatis nom. nov. (Basomym, Cytophaga aquatilis Strohl and Tait 1978). Int J Syt Bacteriol 46(1):128-148

Bishop GS, Hwang J (1992) Use of a cellular ELISA for detection of cell surface antigens. BioTechniques 12:326-330

Borg AF (1960) Studies on myxobacteria associated with diseases in salmonid fishes. American Association for the 
Advancement of Science, Washington, DC, Wildlife Disease $8,85 \mathrm{p}$ (microcards)

Bruno DW (1992) Cytophaga psychrophila (='Flexibacter psychrophilus') (Borg), histopathology associated with mortalities among farmed rainbow trout, Oncorhynchus mykiss (Walbaum) in the UK. Bull Eur Assoc Fish Pathol $12: 215-216$

Bullock GL (1972) Studies on selected myxobacteria pathogenic for fishes and bacterial gill disease in hatcheryreared salmonids. Technical Papers of The Bureau of Sport Fisheries and Wildlife No. 60, Washington, DC

Bullock GL, Conroy DA, Snieszko SF (1971) Myxobacterioses. In: Snieszko SF, Axelrod HR (eds) Diseases of fishes. T.F.H. Publications, Jersey City, NJ, p 60-88

Campbell RC (1974) Statistics for biologists, 2nd edn. Cambridge University Press, Cambridge

Conrad JF, DeCew M (1967) Observations on deformed juvenile coho salmon. Research Briefs, Fish Commission of Oregon 13:129

Crosa JH, Hodges LL, Schiewe H (1980) Curing of a plasmid is correlated with attenuation of virulence in the marine fish pathogen Vibrio anguillarum. Infect Immun 27(3): $897-902$

Crosa JH, Schiewe MH, Falkow S (1977) Evidence for plasmid contribution to the virulence of the fish pathogen Vibrio anguillarum. Infect Immun 18(2):509-513

Cumming CG, Ross PW, Poxton IR, McBride WH (1980) Grouping of $\beta$-haemolytic streptococci by enzyme-linked immunosorbent assay. J Med Microbiol 13:459-461

Dalsgaard I, Hørlyck V (1990) Koldtvandssyge eller Vintersår hos ørreder [Coldwater disease or winter lesions in trout]. Ferskvandsfiskeribladet 88:118-120

Davies RL (1990) O-Serotyping of Yersinia ruckeri with special emphasis on European isolates. Vet Microbiol 22: 299-307

Davis HS (1946) Care and diseases of trout. Research Report no. 12:63-66, U.S. Fish and Wildlife Service, U.S. Dept. of the Interior, U.S. Government Printing Office (cited in Bullock et al. 1971)

De Jong DM, Pate JL, Kirkland TN, Taylor CE, Baker PJ, Takayama K (1991) Lipopolysaccharide like immunological properties of cell wall glycoproteins isolated from Cytophagá johnsonae. Infect Immun 59:2631-2637

Elder BL, Boraker DK, Fives-Taylor PM (1982) Wholebacterial cell enzyme-linked immunosorbet assay for Streptococcus sanquis fimbrial antigen. J Clin Microbiol 16:141-144

Evensen $\varnothing$, Lorenzen $E$ (1996) An immunohistochemical study of Flexibacter psychrophilus infection in experimentally and naturally infected rainbow trout (Onchorhynchus mykiss) fry. Dis Aquat Org 25:53-61

Holt RA (1987) Cytophaga psychrophila, the causative agent of bacterial cold-water disease in salmonid fish. PhD thesis, Oregon State University, Corvallis

Holt RA, Amandi A, Rohovec JS, Fryer JL (1989) Relation of water temperature to bacterial cold-water disease in coho salmon, chinook salmon, and rainbow trout. J Aquat Anim Health 1:94-101

Ison CA, Hadfield SG, Glynn AA (1981) Enzyme-linked immunosorbent assay (ELISA) to detect antibodies in gonorrhoea using whole cells. J Clin Pathol 34:1040-1043

Kauffmann F (1944) Zur Serologie der Coli-Gruppe. Acta Pathol Microbiol Scand 21:20-45

Kent ML, Groff JM, Morrison JK, Yasutake WT, Holt RA (1989) Spiral swimming behaviour due to cranial and vertebral lesions associated with Cytophaga psychrophila infections in salmonid fishes. Dis Aquat Org 6:11-16
Lancefield RC, McCarty M, Everly WN (1975) Multiple mouse-protective antibodies directed against Group B streptococci. J Exp Med 142:165-179

Lehmann J, Mock D. Stürenberg FJ (1988) Zur Ausbreitung der Bakteriellen Kaltwasserkrankheit (BKK) in NordrheinWestfalen. Fischer und Teichwirt 7:206-207

Lehmann J, Mock D, Stürenberg FJ, Bernardet JF (1991) First isolation of Cytophaga psychrophila from a systemic disease in eel and cyprinids. Dis Aquat Org 10:217-220

Lorenzen $E$ (1993) The importance of the brand of the beef extract in relation to the growth of Flexibacter psychrophilus in Anacker \& Ordal's medium. Bull Eur Assoc Fish Pathol 13:64-65

Lorenzen E, Dalsgaard I, Bernardet JF (1997) Charecterization of isolates of Flavobacterium psychrophilum associated with coldwater disease or rainbow trout fry syndrome I: phenotypic and genomic studies. Dis Aquat Org 31:197-208

Lorenzen E, Dalsgaard I, From J, Hansen EM, Horlyck V, Korsholm, H, Mellergaard S, Olesen NJ (1991) Preliminary investigations of fry mortality syndrome in rainbow trout. Bull Eur Assoc Fish Pathol 11:77-79

Meyers TR (1989) Apparent chronic bacterial myeloencephalitis in hatchery reared juvenile coho salmon Oncorhynchus kisutch in Alaska. Dis Aquat Org 6:217-219

Mills KW, Phillips RM, Kelly BL, Baughman GL (1982) Using enzyme-linked immunosorbent assay to detect Escherichia coli K88 pili antigens from clinical isolates. Am J Vet Res 43:365-367

Pacha RE (1968) Characteristics of Cytophaga psychrophila (Borg) isolated during outbreaks of bacterial cold-water disease. Appl Microbiol 16:97-101

Pacha RE, Porter S (1968) Characteristics of myxobacteria isolated from the surface of freshwater fish. Appl Microbiol 16:1901-1906

Reichenbach $H$, Dworkin M (1981) Introduction to the gliding bacteria. In: Starr MP, Stolph H, Trupher HG, Balows A, Schlegel HG (eds) The procaryotes, Vol. 1, Springer-Verlag, New York, p 315-327

Roitt I (1984) The immunoglobulins. In: Essential immunology, 5th edn. Blackwell Scientific Publications, Oxford

Santos Y, Huntly PJ, Turnbull A, Hastings TS (1992) Isolation of Cytophaga psychrophila (Flexibacter psychrophilus) in association with rainbow trout mortality in the United Kingdom. Bull Eur Assoc Fish Pathol 12:209-210

Sarti M, Giorgetti G, Manfrin A (1992) Method for the rapid diagnosis of visceral myxobacteriosis in reared trout in Italy. Bull Eur Assoc Fish Pathol 12:53

Schachte JG (1983) Coldwater disease. In: Meyer FP, Warren JW. Carey TG (eds) A guide to integrated fish health management in the great lakes basin. Great lakes Fishery Commission, Ann Arbor, MI, p 193-197

Tijssen P (1987) Practice and theory of enzyme immunoassays. Elsevier, Amsterdam

Toranzo AE, Barja JL (1993) Fry mortality syndrome (FMS) in Spain. Isolation of the causative bacterium Flexibacter psychropilus. Bull Eur Assoc Fish Pathol 13: 30-31

Toranzo AE, Barja JL, Colwell RR, Hetrick FM (1983) Characterization of plasmids in bacterial fish pathogens. Infect Immun 39(1): 184-192

Voller A, Bidwell DE, Barlett A (1979) The enzyme linked immunosorbent assay (ELISA). A guide with abstracts of microplate applications. Nuffield Laboratories of Comparative Medicine, Zoological Society of London

Wakabayashi $H$, Toyama T, lida T (1994) A study on serotyping of Cytophaga psychrophila isolated from fishes in Japan. Fish Pathol (Gyobyo Kenkyu) 29:101-104 
Weis $J(1987)$ Über das Vorkommen einer Kaltwasserkrankheit bei Regenbogenforellen, Salmo gairdneri. Tierärztl Umschau 42:575-77

Westphal O, Jann K (1965) Bacterial lipopolysaccharides. Extraction with phenol-water and further applications of the procedure. Methods Carbohydr Chem 5:83-91

Editorial responsibility: Trevor Evelyn,

Nanaimo, British Columbia, Canada
Wood JW (1974) Diseases of Pacific salmon: their prevention and treatment, 2nd edn. Hatchery Division. Washington Department of Fishenes, Olympia, WA

Wood JW, Yasutake TW (1956) Histopathology of fish. III. Peduncle ('cold-water') disease. Prog Fish-Cult 18: $58-61$

Submitted: September 1, 1995; Accepted: October 8, 1997 Proofs received from author(s): Decermber 22, 1997 